\title{
Sustainable Decommission of Mining Lands: Landform Design for Eaton Tuner Shaft (ETS) Area, Obuasi, Ghana
}

\author{
Kwadwo Twumasi-Ampofo ${ }^{1 *}$, Charles F. A. Akayuli ${ }^{1}$, Daniel Asenso-Gyambibi ${ }^{1}$, Bernard Ofosu ${ }^{1}$, \\ Kwabena Osei Opuni ${ }^{1}$, Leonard Makafui Koblavie ${ }^{1}$ and Abeiku Arthur,Jnr, ${ }^{2}$ \\ 1. CSIR- Building and Road Research Institute, P. O. UP40, KNUST-Kumasi, Ghana \\ 2. Anglogold Ashanti, Obuasi, Ghana \\ * E-mail of corresponding author: kktwumasi2002@yahoo.co.uk
}

\begin{abstract}
Ghana is the first country in the Sub-Sahara African region to reform its mining sector and has become the poster child for such change in the developing world. Obuasi is the hub of gold mining in Ghana. The Obuasi mine is currently operated by AngloGold Ashanti (AGA), and contributes immensely to the Gross Domestic Product (GDP) of Ghana. Mining is however, an activity that causes disturbance to the natural habitat and threatens biodiversity. Mining of mineral resources results in extensive soil damage, altering microbial communities and affecting vegetation leading to destruction of vast amounts of land which needs to be reclaimed and restored. Reclamation is the process to restore the ecological integrity of these disturbed mine land areas. Mining at the Eaton Tuner Shaft (ETS) area has been decommissioned and this paper seeks to explain processes leading to the sustainable design of a safe and suitable landform for the ETS as part of closure plan by reclaiming the vast land currently in the heart of Obuasi town. This is an exploratory study employing survey methods, geotechnical profiling and topographical survey to obtain data for the landform design and ultimate land reclamation. The study revealed that the soils at the ETS area have an upper stratum of sandy Gravels underlain by strata of silts or sands with average plasticity index of $14.46 \%$ and can be used as fill material with mean allowable bearing capacity between $781 \mathrm{KPa}$ and $1,413 \mathrm{KPa}$. For a sustainable landform design, the study recommends a gentle slope transitions of about $2.5 \%$ and $1: 2$ for embankments.
\end{abstract}

Keywords: Reclamation, Mining lands, Sustainable decommissioning, Landform design, Obuasi

DOI: $10.7176 / \mathrm{JEES} / 9-12-07$

Publication date: December $31^{\text {st }} 2019$

\section{Introduction}

Mining contributes significantly to Ghana's economy, employing about 260,662 people (GSS, 2012) and accounts for about 9.1\% of Ghana's GDP (GSS, 2014). Mining however, is accompanied with adverse environmental impact including water contamination, destruction of flora and fauna, land degradation, and mercury contamination of soils and water (Al-Hassan \& Amoako, 2014; Babut et al., 2003; Bonzongo et al., 2003; Hilson, 2002). Reclamation of mining lands has been a major challenge in recent times due to degradation of vast lands which originally was used as nature reserve and farming purposes. Reclamation has also become impossible as a result of illegal mining in Ghana. Rinkesh (2009), states that illegal mining tend to cause disturbances to the natural habitat and hence threatening biodiversity.

There are also reported cases of disregard for basic safety protocols resulting in death, damage to property and to the environment (Al-Hassan \& Amoako, 2014). Exploitation of mineral resources creates a large area of degraded lands and loss of land for agriculture that need reclamation (Hilson and Banchirigah, 2009; Aryeetey et al., 2004; SAPRIN, 2002). Impact of mining on land environment is reflected in land-use pattern of the respective area. This is evident by erosion, whereby the land loses its green cover or is disturbed by mining activities causing threat to agricultural lands (Owusu-Ansah, 2012). These mining activities may occur on abandoned lands which usually results in water pollution caused by toxic waste thus poses health problems (Akabzaa and Darimani, 2001), serious threat to development and security (Maconachie and Binns 2007). Abandoned mine lands referred to as post mining site reclamation and restoration is the final and crucial stage, which requires proper planning and should not be confined necessarily towards the decommissioning phase of the entire project. Reclamation should be progressive such that rate of restoration is more or less similar to the rate of mining (Bhattacharya, 2005). Reclamation refers to the returning of disturbed lands to an improved state (Skousen and Ziemkiewicz, 2012). This involves the process of creating or reconverting disturbed land to its former or other productive uses (Powter, 2002). This is achieved by redesigning the landform and re-vegetation 
to protect the soil surface from erosion, making the land hospitable to organisms that were originally present and using the land for industrial or infrastructural purposes (Rinkesh, 2009). Landform design is an essential part of reclamation in developing mineral resources in accordance with the principles of ecologically sustainable development. In most cases, direct reestablishment of trees on surface mine tailing lands is difficult, considering the degraded soil physical conditions and severe deficiency of soil nutrients (Evans et al., 2013). But this can be achieved by selecting plants with the ability to survive and regenerate or reproduce under severe conditions (Madejon et al., 2006). Land reclamation, with a better landform design, can provide us with environmental and economic benefits, for example, soil erosion prevention, atmospheric CO2 sequestration, wildlife habitat, and fuel wood supply (Guzman et al., 2014).

\subsection{History of Mining in Ghana}

Mining in Ghana can be traced back to the 7th and 8th century AD with alluvial gold extraction and winning activities strategically along rivers which attracted Arab traders into the country (Gavin, 2001; Hilson, 2002b). Some of the minerals mined include gold, bauxite, manganese, diamond, salt and lime stone with gold being the major mineral mined in commercial quantities. Akabzaa, (2001) claims that the nation was referred to as the "Gold Coast" because gold was and is the dominant mineral extracted and contributes to more than $90 \%$ of the minerals extracted.

Ghana is one of many countries in sub-Saharan Africa where an informal gold mining economy has been intentionally created. It is the first country in the region to reform its mining sector, and has become the poster child for such change in the developing world. Today, Ghana produces over 2 million ounces of gold per year. Over the past 80 years, many foreign companies have entered the mining and quarrying industry in Ghana. Some of the biggest players in mining include Anglo Ashanti, Golden Star, Newmont, Akola, Ghana Manganese (Mining portal of Ghana, 2013). Ghana is currently second to South Africa in Africa in terms of gold exploration, manganese (the third largest), aluminium and a major producer of bauxite as well as diamonds (KPMG, 2014)

AngloGold Ashanti (AGA) operates a gold mine located at Obuasi in the Ashanti Region of Ghana. This is an open-pit and underground gold mine situated near Obuasi and a history of gold mining for over 112 years (World's top gold deposits, 2013). The Obuasi mine, as part of its footprint reduction programme to promote sustainable development has decommissioned the Eaton Tuner Shaft (ETS) and stripped the area of mining infrastructure. An integration of environmental, economic and social aspects through all phases of mineral production from exploration through construction, operation and mine site closure is therefore essential. The Central Business District (CBD) of Obuasi has grown closer to the decommissioned site and calls for immediate attention.

The aim of this study is to design a landform for the reclamation of the ETS decommissioned mining area for sustainable development of the Obuasi town. This study therefore serves as a basis for future rehabilitation and restoration. The main objective of this assignment is to propose a design depicting a safe and suitable landform for the ETS area that blends with the surrounding topography and intervene depressions conducive for future land use options.

\section{Study Area, Materials and Methods}

\subsection{Description of the Project Site}

The study area (ETS) is bordered on the north by TTP, on the west by the central business district (CBD) of Obuasi and on the south and east by the Wawasi Township which has the Kwabrafo River flowing through. The site (Figure 1) is undulating with the maximum and minimum elevations being $235 \mathrm{~m}$ and $205 \mathrm{~m}$ respectively. The ETS area with a total area of about $193,793 \mathrm{~m} 2$, had been cleared of all mining infrastructure on the surface with the underground shaft capped and ramp access also seal off. Some surface areas were covered with mine rock waste. Demolishing and removal of concrete and steel structures had begun at the TTP with remnants of the past usage such machines and ponds still present. Further, there were existing concrete slabs on various sections of the ground at TTP. The vegetation cover at the site consists of shrubs and grasses interspersed with some. An access road beginning at the main gate runs outside the fence wall of the ETS then across it between the ETS and TTP. A few well defined concrete drains were also observed but they had no running water in them. Figure 1 shows the location of the project location. 


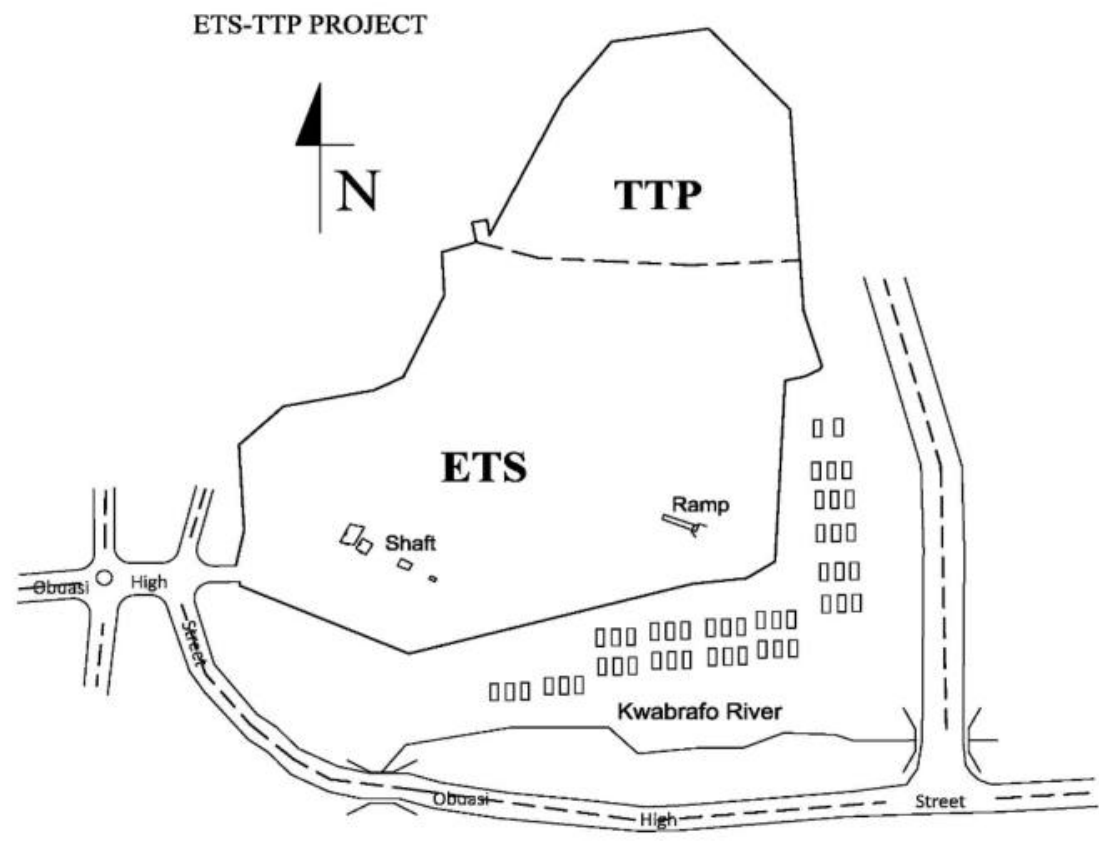

Figure 1. Location of the study Area. Source: AGA Envioromental section, Obuasi

\subsection{Materials and Methods}

Survey of the study area (Figure 1) was conducted beginning with site reconnaissance visits and determine spot heights. Other methods for the study include desk studies, geotechnical profiling (trial pitting, dynamic cone penetration tests - DCPT, laboratory testing and slope stability analysis), topographical survey, landform design and drainage design.

Desk study was undertaken to review available literature on mine rehabilitation, landform design and other related aspects of the project. The available literature provided information on some specifics associated with the fieldwork and design criteria required for carrying out the project successfully. The relevant literature included geology, topography, history and hydrological and topographical information. Reconnaissance survey was undertaken in May, 2015 to familiarize with the project and understand the scope of the study. The following were observed during the survey; demolitions of concrete structures were ongoing, the subsurface soils at some parts of the site consist of loose gravely sand with boulders, steep embankment with slopes ranging between $60 \mathrm{o}$ to $90 \mathrm{o}$. The height also ranges between $2 \mathrm{~m}$ to $5 \mathrm{~m}$, undulating topography with some vegetation cover in some areas. Fieldwork started on the 27th of August to 30th October, 2015. Subsoil investigations were conducted to obtain soil samples for laboratory tests. This enabled the classification of the subsurface soils and also determination of the engineering properties of the soils for stability analysis. The approach adopted for the investigations during the field work is presented below:

Six trial pits were excavated using a backhoe to a maximum depth of $2.5 \mathrm{~m}$. Four (4) of the pits were in the ETS area and two (2) in the TTP compound. Each trial pit was logged and bulk soil samples taken, bagged and labeled for subsequent laboratory testing. Groundwater was not encountered at the depths excavated. Typical trial pits excavated in the ETS and the TTP are presented in Figure 2. Logs of the trial pits are presented in Appendix A. 

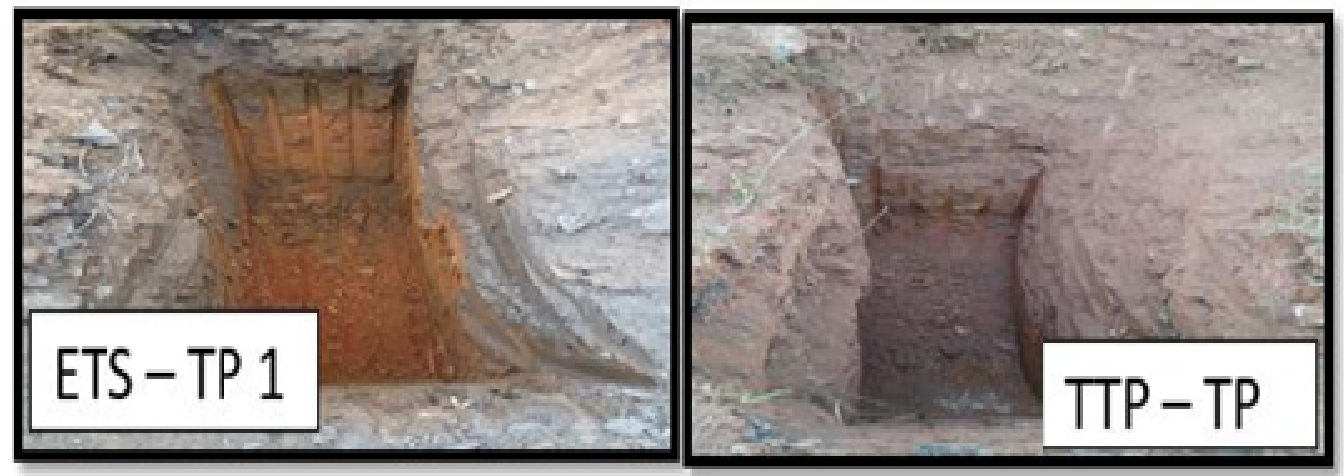

Figure 2. Typical Trial Pits in the ETS and TTP Area. Source: Authors, 2015

Dynamic Cone Penetration Tests (DCPT) were conducted at selected locations at the study area to obtain the in situ strength (Figure 3). The purpose of the tests is to determine allowable bearing capacity of the ground formation for infrastructure development at the project site. The German model, DIN 4094 DCP equipment with a $10 \mathrm{~kg}$ hammer and $90 \mathrm{o}$ cone angle was used for the DCP test. A total of 16 DCP tests were undertaken, twelve tests were conducted at the ETS site and four at the TTP site. Figure 3 shows DCP tests in progress at the project site and the locations of the tests points and trial pit locations are shown in Figure 4.

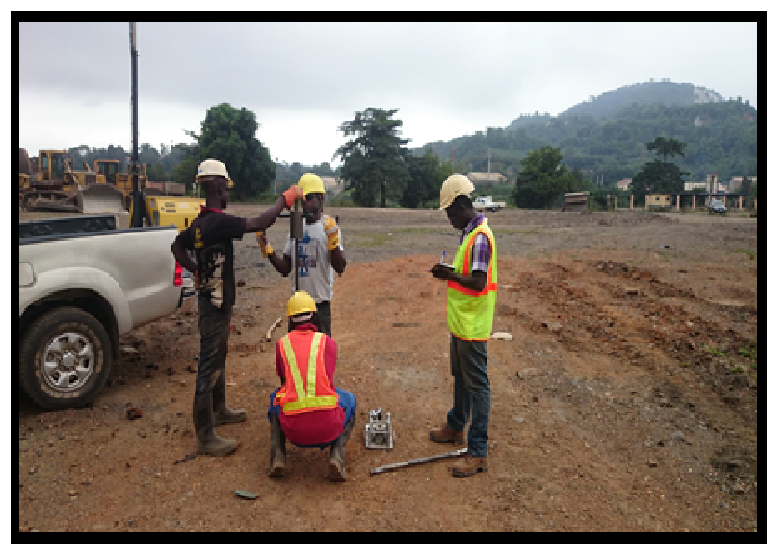

Figure 3. Dynamic Cone Penetration Tests at the Project Site. Source: Authors, 2015 


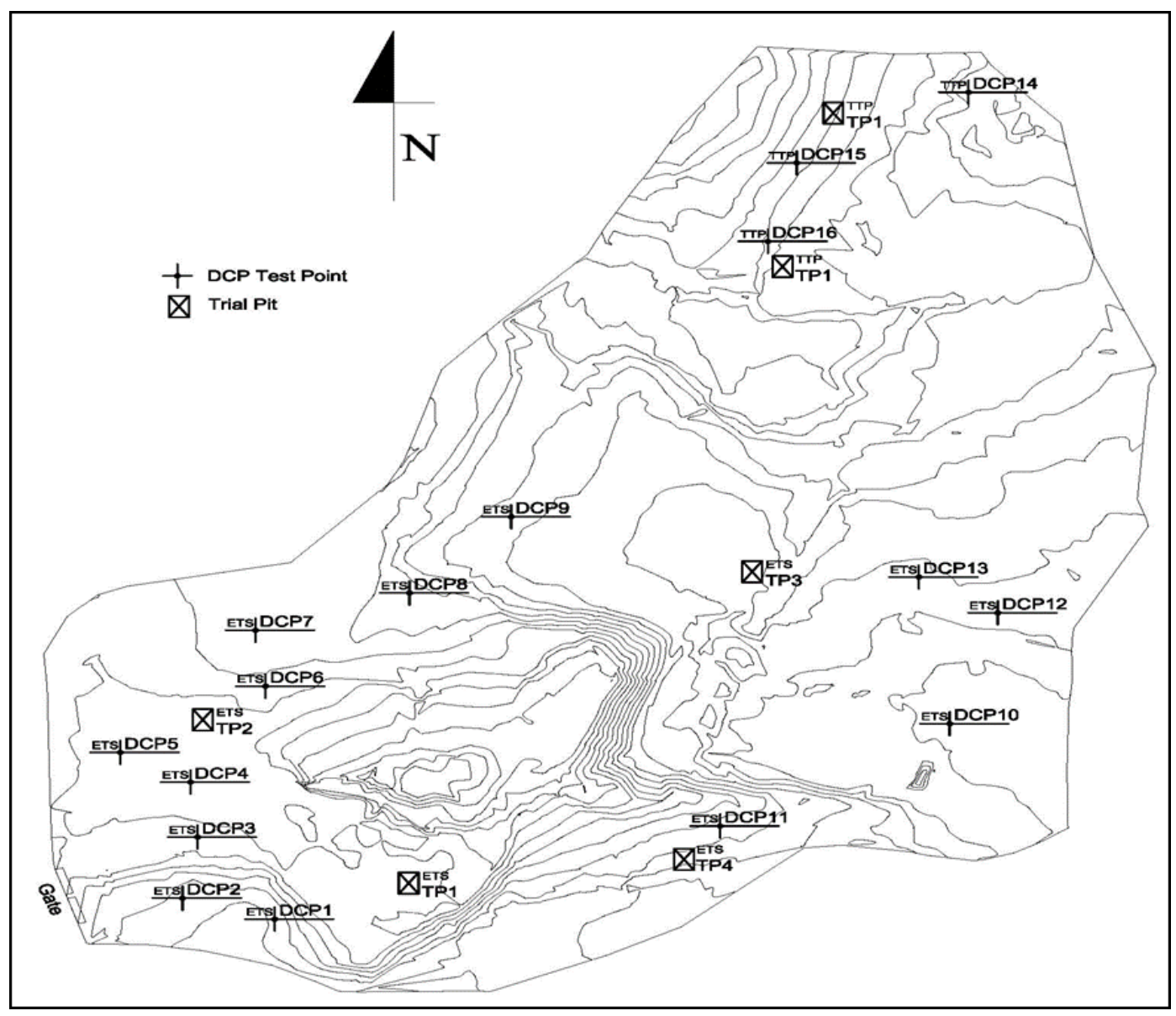

Figure 4. Location of the Trial Pits and the DCPT Points .Source: Authors, 2015

The soils obtained from the trial pits were subjected to laboratory tests in accordance with BS 1377 190. The tests included, moisture content, specific gravity, particle size distribution, direct shear and proctor compaction.

The survey commenced on the 31st of August 2015 and was completed on 5th of October 2015. With the assistance from AngloGold, a point of departure was identified as SLM 002 with coordinates $168673.963 \mathrm{~N}$ 201077.648E with height of 230.476 located near the Malaria Control Office. GPS and Total Station were used to capture all the relevant data for map preparation. This included buildings, spot levels, existing ETS Shaft and ramp. The Instrument employed in establishing the pillars was Real Time Kinematic (RTK) a Global Positioning System equipment. The projection employed is the cylindrical projection (Universal Traverse Mercator, Zone 30). The unit observed for the data collected was meters. In total, 2261 points were collated between the TTP and the ETS locations using Sokkia total station equipment.

\subsection{Landform Design}

Mining, no matter how sustainable it is executed, disturb the environment and at Post-closure, there is the need to rehabilitate the disturbed area such that it blends in with the surrounds, has minimal offsite impact and is environmentally sustainable. This requires that hill slopes, shape and length of the mined landform be designed to become erosionally stable (Hancock and Willgoose, 2017). Post-mining rehabilitation projects fail because the landscape is unable to sustain functional ecosystems and/or because the export of sediments has and can affect ecosystems downslope and downstream (Evans, 2010; Nicolau, 2003). For any mine, a reconstructed landscape must be designed to achieve a long-term viable ecosystem while releasing sediment at a minimal rate and geochemically compatible with the surrounding undisturbed landscape. Consequently, landform stability over the 
long term is essential for a sustainable functioning ecosystem (Hancock and Willgoose, 2017). The objectives for designing landform cover systems include control of water erosion, chemical stabilization of acid-forming mine drainage (through control of oxygen ingress), contaminant release control (through control of infiltration) and providing a growth medium for vegetation establishment (O'Kane and Wels 2003). Mine landform reconstruction should as much as possible conform to pre-existing catchment boundaries and drainage densities (Toy and Chuse, 2005). Designing hill slopes with curvature can also restore natural patterns of water and sediment distribution (Hancock et al., 2003). Nicolau (2003) posits that relief is a key ecological design parameter to consider in reconstructing the landscape. Landform design involves backfilling of redundant/final voids including ramps and mine void that have been identified as no longer needed for other strategic uses taking into account material types and selective handling requirements as per mandated material management implemented through the earthworks. Landform and re-profiling of mining sites are very important for rehabilitation and regulating of mineral sites in accordance with the requirements of the minerals and mining (Health, Safety and Technical) regulations, 2012 (LI 2182). It must be said that mining activities are only temporary activities which are undertaken for a limited number of years, after which the land is supposed to be reclaimed and restored for another use. According to the National Planning Policy Framework of the Department for Communities and Local Development-UK (2014), the following are the key stages to be considered in reclamation and restoration of mineral sites: stripping of soils and soil-making materials and either their storage or their direct replacement (i.e. 'restoration') on another part of the site; storage and replacement of overburden; achieving the landscape and landform objectives for the site, including filling operations if required, following mineral extraction; restoration, including soil placement, relief of compaction and provision of surface features and aftercare. These stages in effect, suggest that all holes, removal of plant-sand vegetation created as a result of consistent excavation should be filled or replaced. Computer application software such as Autodesk AutoCAD, ArcGIS, PDF Creator and Adobe Photoshop were used to convert the data and concepts into drawing layouts, diagrams, 3-dimensional models and photorealistic views. Also conceptual sketches were used to have perceived images of the landform design project which is one the fundamental approach to landscape design. The embankment was divided into four sections (Figure 5), based on the gradient of the existing slopes and analysed with respect to the final designed landform. The parameters considered for the stability analysis included the shear strength, internal angle of friction and Cohesion factors (Table 1). The stability analysis was done using SLIDE 5.0 from Rocscience Inc. The analysis utilized the Morgenstern Price limit equilibrium method.

Table 1. Soil Parameters Used In Slope Stability Analysis

\begin{tabular}{|c|c|c|c|c|c|c|c|}
\hline \multirow[b]{2}{*}{ Material } & \multirow[b]{2}{*}{ Description } & \multicolumn{2}{|c|}{$\gamma\left(\mathrm{kN} / \mathrm{m}^{3}\right)$} & \multicolumn{2}{|c|}{$\phi$ (degrees) } & \multicolumn{2}{|c|}{$\mathrm{C}\left(\mathrm{kN} / \mathrm{m}^{2}\right)$} \\
\hline & & Static & $\begin{array}{l}\text { Pseudo } \\
\text { static }\end{array}$ & Static & $\begin{array}{l}\text { Pseudo } \\
\text { static }\end{array}$ & Static & $\begin{array}{l}\text { Pseudo } \\
\text { Static }\end{array}$ \\
\hline Embankments & $\begin{array}{lll}\text { Silty } & \text { SAND/ sandy } \\
\text { SILT } & & \\
\end{array}$ & 16 & 12.8 & 32.5 & 26 & 20 & 16 \\
\hline
\end{tabular}




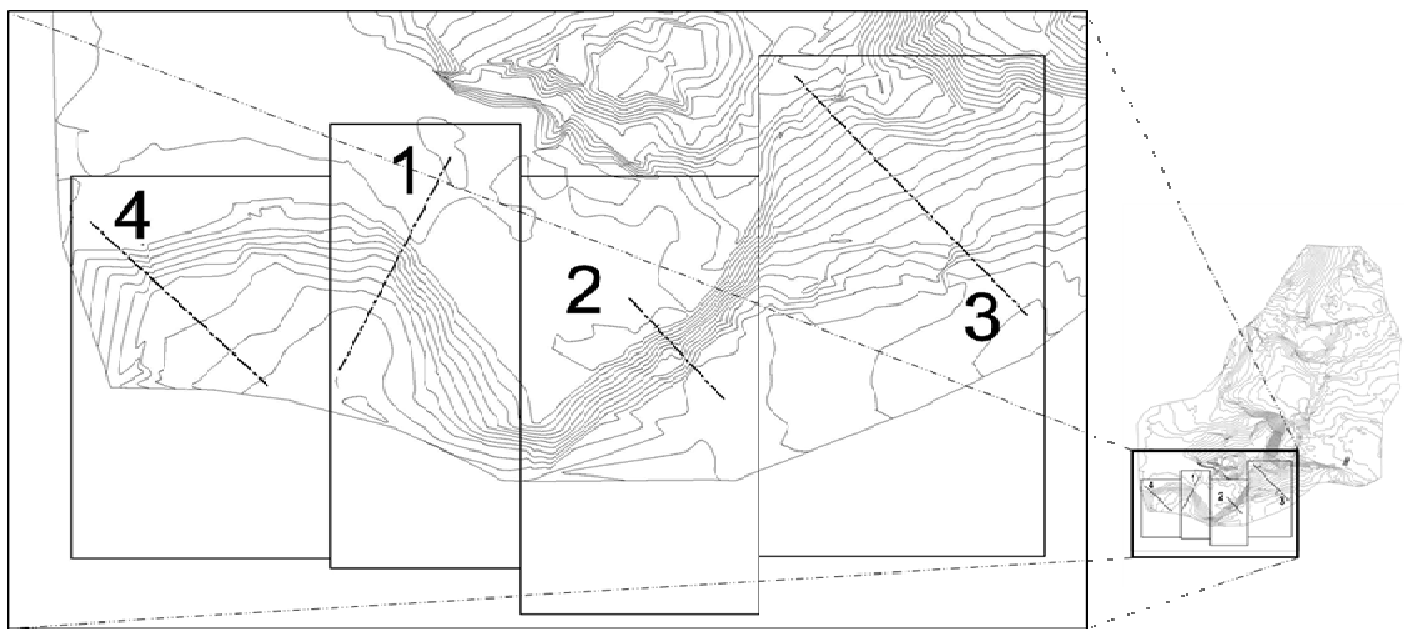

Figure 5: Embankment Sections. Source: Authors, 2015

\subsection{Drainage Design}

Rainfall on a catchment is temporarily stored on vegetation as interception, fills natural depressions in the landscape and it infiltrates into the soil. After these demands are satisfied, water starts flowing over the land and this generates runoff. An effective drainage system is essential to ensure runoff from catchments does not cause nuisance, danger and damage to people, property and the environment. During a walkover survey of the project area, a number of drains were observed. They included a 550x350mm rectangular road side on the east of ETS, and a 900x900mm rectangular road side on the west after the housing unit (Figure 8). The 900x900mm drain receives flow from these households and discharges them to an end box culvert along the path of the Kwabrafo River.

\subsubsection{Hydraulics Analysis}

By use of calculations evaluation of appropriate channel cross-sections and grades to permit flow at allowable velocities is critical. The Road Design Guide, Ghana Highways Authority recommends a freeboard of $20 \%$ to $30 \%$ to cater for possible siltation which reduces the effective area of flow within a channel.

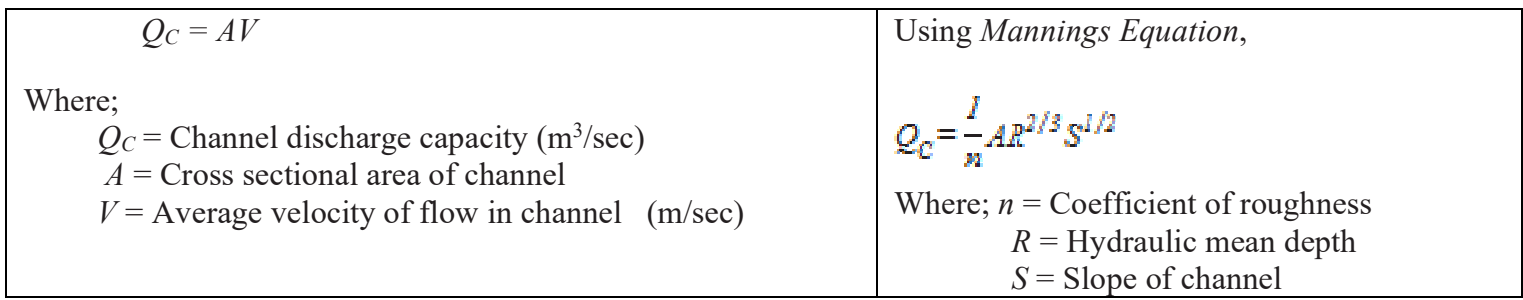

\subsubsection{Hydrological Analysis}

Several environmental factors affect the volume of water that contributes to surface runoff. These conditions include rainfall duration and intensity, topography, land use, vegetation coverage and soil type. Obuasi falls within the wet semi-equatorial climatic zone with a double rainfall seasons characterized by torrential rainfall and high humidity. The Obuasi Municipality has an undulating topography with its vegetation being predominantly made up of degraded and semi-deciduous forests (Dickson \& Benneh, 1980). The Rational Method is a statistical method used to calculate peak discharge from a catchment. This method was used as it provides a simplistic methodology for estimating the design peak flow rate to enable the determination of the sizes of drainage systems. The Rational Method has a general procedure as follows: determine catchment area; estimate time of concentration; determine design rainfall intensity; estimate runoff coefficients and compute peak flow for catchment. The Rational Method formula is: 


\begin{tabular}{|c|c|c|}
\hline $\begin{array}{l}\qquad Q=0.278 C I A ; \\
\text { Where; } Q=\text { Maximum runoff from the catchment area } \\
\left(\mathrm{m}^{3} / \mathrm{sec}\right) \\
C=\text { Runoff coefficient } \\
I=\text { Average rainfall intensity }(\mathrm{mm} / \mathrm{h}) \\
A=\text { Catchment area }\left(\mathrm{km}^{2}\right) \\
\text { The time of concentration } t_{c} \text { can be computed using: } \\
\qquad t_{c}=t_{o}+t_{c h} \\
\text { Where; } \\
t_{c}=\text { time of concentration (minutes) } \\
\mathrm{t}_{o}=\text { overland sheet flow time (minutes) } \\
\mathrm{t}_{c h}=\text { travel time in channel (minutes) }\end{array}$ & $\begin{array}{l}t_{0}=107 \frac{n L^{1 / 3}}{s^{1 / 2}} \\
\text { Where; } \\
\mathrm{L}=\text { overland } \\
\text { sheet flow path } \\
\text { length (m) } \\
\mathrm{n}=\text { Manning's } \\
\text { roughness } \\
\text { coefficient } \\
\mathrm{S}=\text { Slope of } \\
\text { overland } \\
\text { surface (\%) }\end{array}$ & $\begin{array}{l}t_{\mathrm{ch}}=\frac{n \mathrm{n}}{60 R^{2 / 3} 5^{1 / 2}} \\
\text { Where; } \\
\mathrm{n}=\text { Manning's roughness } \\
\text { coefficient } \\
\mathrm{L}=\text { Channel length }(\mathrm{m}) \\
\mathrm{R}=\text { Hydraulic radius }(\mathrm{m}) \\
\mathrm{S}=\text { Friction slope }(\mathrm{m} / \mathrm{m})\end{array}$ \\
\hline
\end{tabular}

\section{Results and Data Analysis}

\subsection{Subsurface Soils}

Laboratory tests on the subsurface soils from the excavated trial pits at the ETS area indicates a ground formation which consist a ground depth of about $0.4 \mathrm{~m}$. This material is underlain by predominantly dense gravelly sand with varying proportion of clay and silts. The soils at the ETS area have an average Plasticity Index of $14.46 \%$ with average specific gravity of $2.6 \mathrm{~m}$. The TTP area is also made of a top soil of about $0.3 \mathrm{~m}$ below the ground surface; it is underlain by firm Clayey Silt with varying proportions of sand and gravel. The TTP soils also have an average Plasticity Index of $11.14 \%$ and specific gravity of 2.5 . The values of the plasticity index indicate that, soils have low plasticity and devoid of any compressible properties. Proctor compaction on the soils excavated from the trials pits resulted in Maximum Dry Density (MDD) between 1.65 $\mathrm{g} / \mathrm{cm} 3$ and $1.7 \mathrm{~g} / \mathrm{cm} 3$, which means the soils from the project area can be used as fill material during the earthworks.

\subsection{In-situ Strength}

The allowable bearing capacity was calculated from the DCPT penetration values using a correlation proposed by Sower and Hedges (1966) as: qa $=44 \mathrm{~N}$. Where: $\mathrm{qa}=$ allowable bearing capacity; $\mathrm{N}=$ the number of blows that drives a $100 \mathrm{~mm}$ segment of the DCP rod into the soil. Figure 8 shows the mean allowable bearing capacity against depth in the project area. The mean allowable bearing capacity ranges between $781 \mathrm{KPa}$ and $1,413 \mathrm{KPa}$ (Figure 6). The presence of waste rock fill overlying the natural ground resulted in very high values in the top soil. 


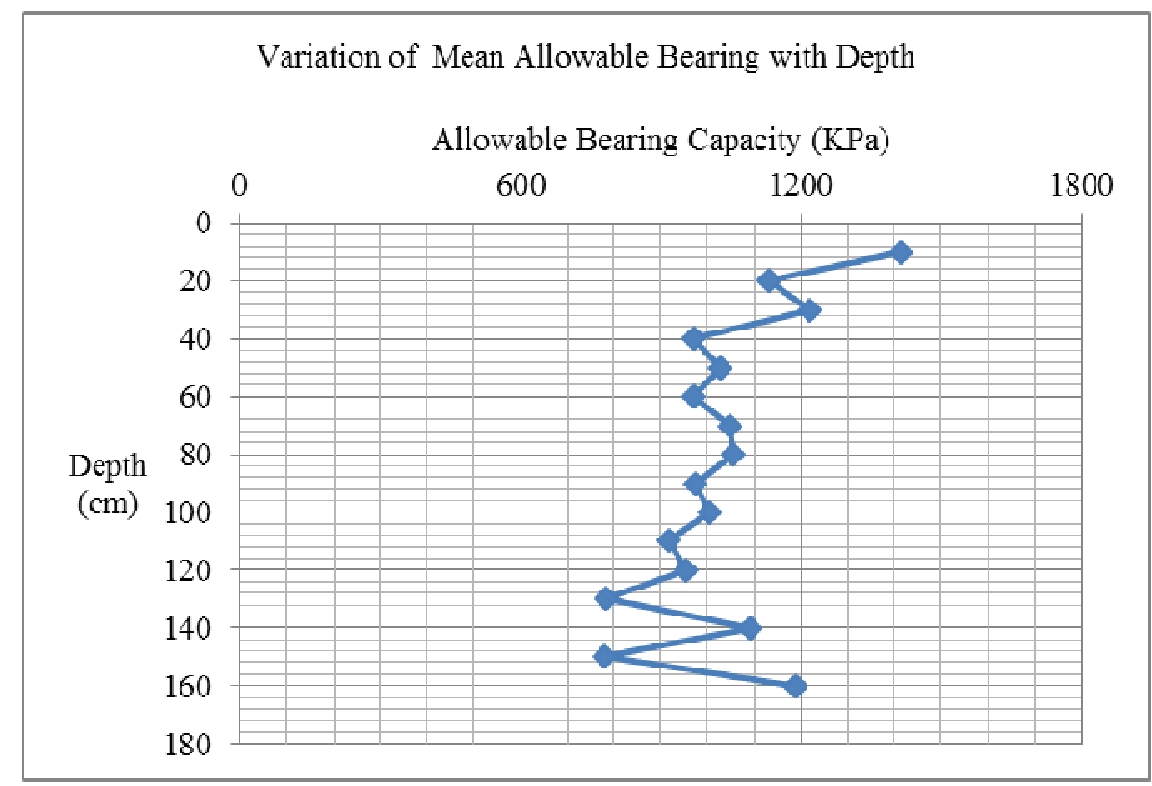

Figure 6: Variation of Mean Bearing Capacity with Depth Source: Authors, 2015

\subsection{Topographical Survey}

The data captured from the fieldwork was processed and used to generate maps for the landform. Figure 7 shows the number of elevations captured from the project site with elevations ranging from $200 \mathrm{~m}$ to $240 \mathrm{~m}$.

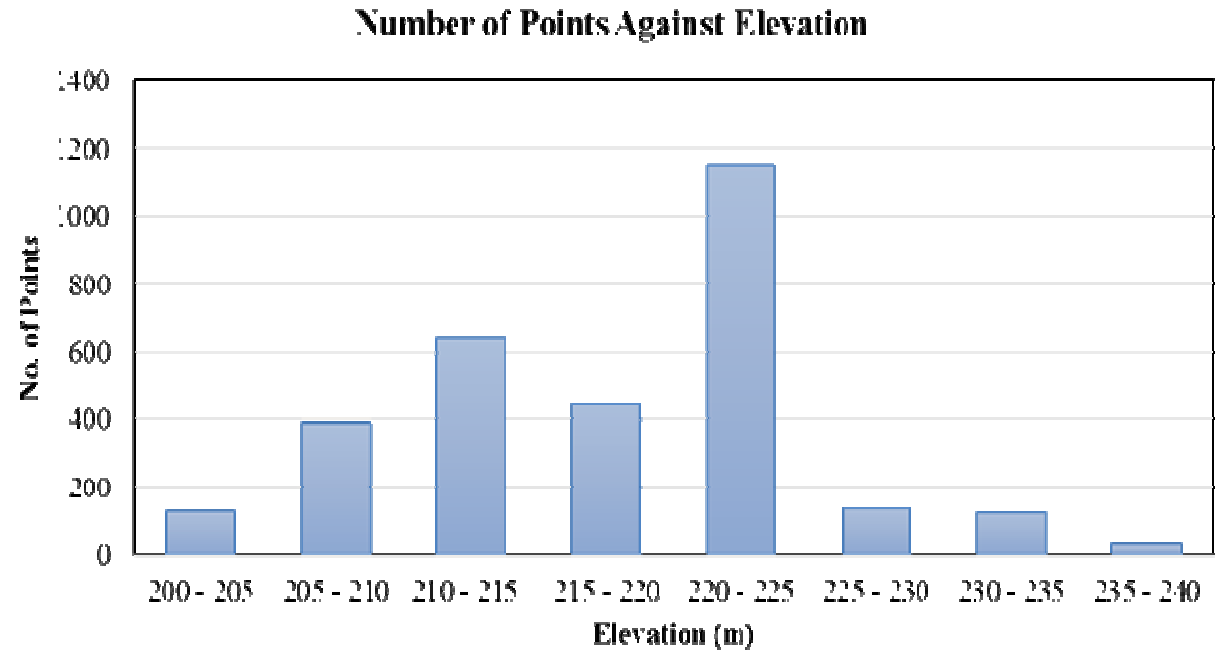

Figure 7. Graph of Number of Points against Elevation Source: Authors, 2015 
With computer aided design software, the existing site was modeled to show the various levels both in solid model and wireframe model (Figure 8).
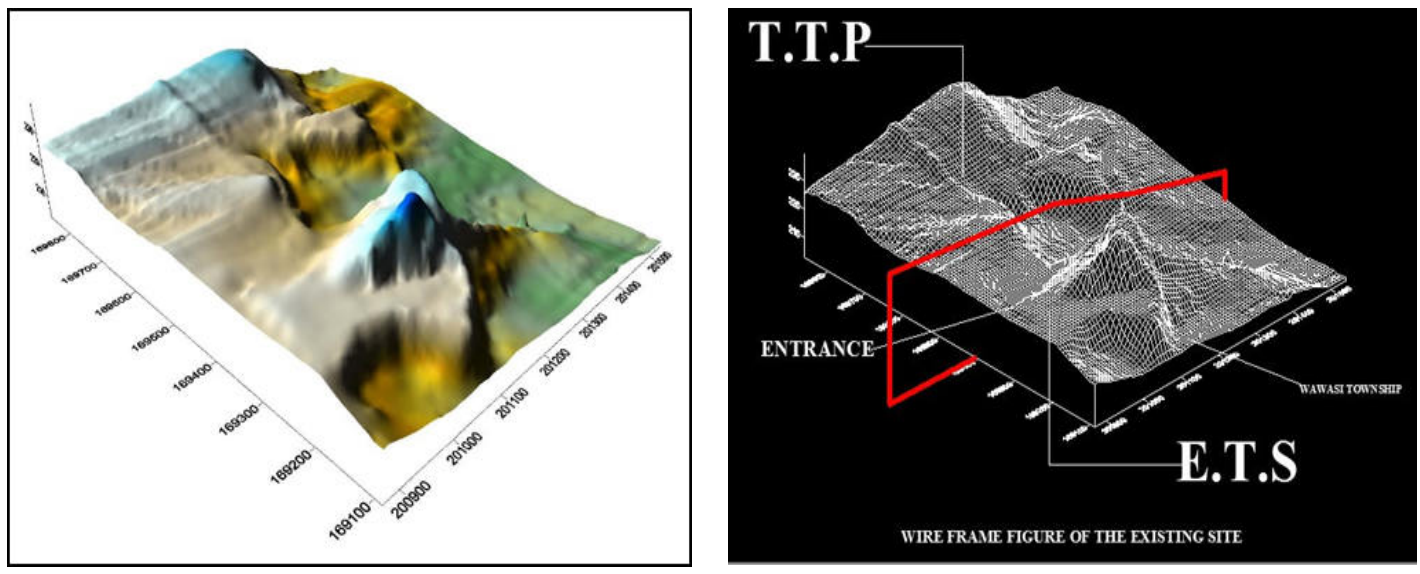

Figure 8. 3-D solid and wireframe of Existing Landform of ETS Area. Source: Authors, 2015

\subsection{Design Considerations for the Proposed Landform}

Relating the information obtained from the geotechnical investigations and land survey, the following approach was used: the concept took into consideration the existing slope and drain water system such that there would be no reverse of drainage lines in a way of ensuring the natural flow lines for run-off water. The landform also took into account the WAWASI Township which lied low on the right side from the main entrance. This landform was conceptualized to drain water away from the township such that the highest level $(+236)$ will be cut to $(+225)$ which falls in line with the ETS Entrance from the AGA Roundabout (Figure 9). The height difference of $11 \mathrm{~m}$ will be used to fill a depth of $10 \mathrm{~m}$ as shown in figure 12 . The design also considered the existing form of the TTP area such that; it's natural slope runs and converge with the ETS at levels $+219,+218$ and +215 which maintains the natural flow of water from the two areas.

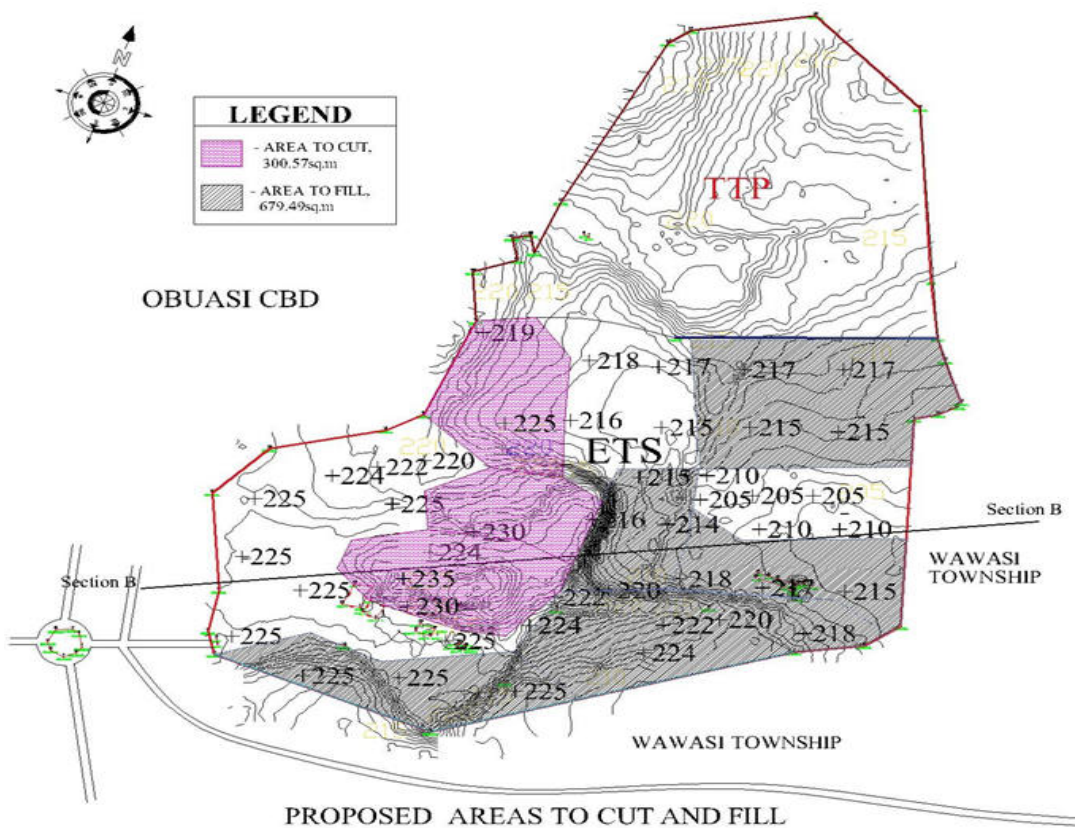

Figure 9. Cutting the higher points to fill the lower points. Source Authors, 2015 


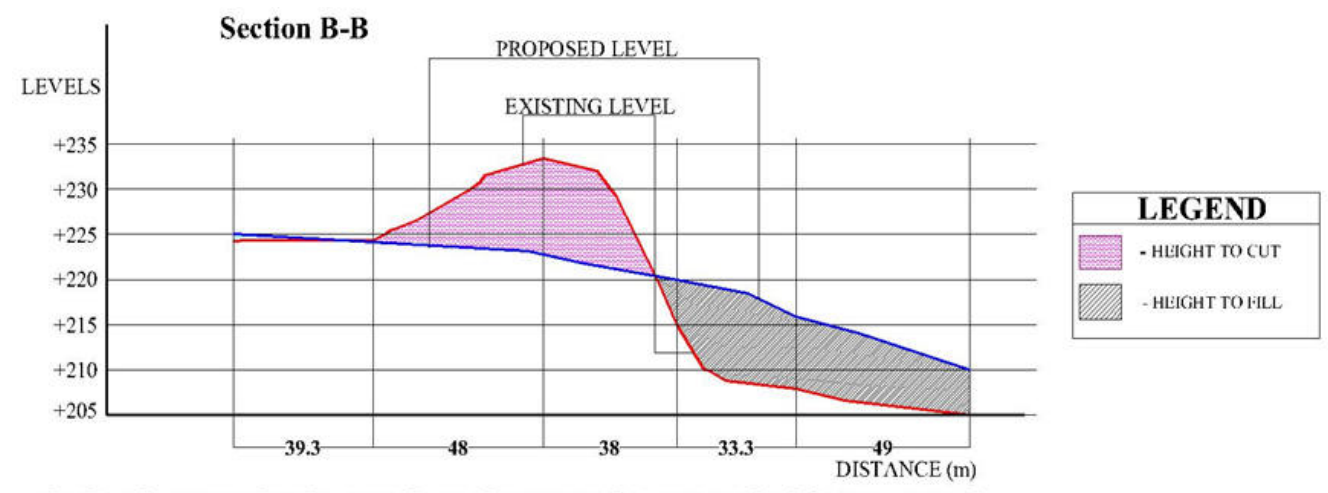

\section{SECTION THROUGH EXISTING LEVELS AND PROPOSED LEVELS}

Figure 10. Cut and fill points. Source Authors, 2015

\subsection{The Landform Design (Reclamation)}

From the main entrance height $(+225)$, the new designed spot height is gradually reduced away from the town (Obuasi CBD) to the existing valley and drain (at the lowest level of +205 ) which gently enters the drainage system of the Wawasi town at a relatively lower level in a multiple outlet as shown in figure 11. The design eliminates any defined steep slope (sharp change in levels) to keep the landform easily accessible by cutting higher points above $225 \mathrm{~m}$ to fill the lower points to facilitate future development and reduce importation of fill material from outside the study area as indicated in figure 12 cross section B-B. To achieve gentle slope for the new design, the lower spot heights were filled by materials cut from the higher spot heights and if necessary borrow materials from outside.

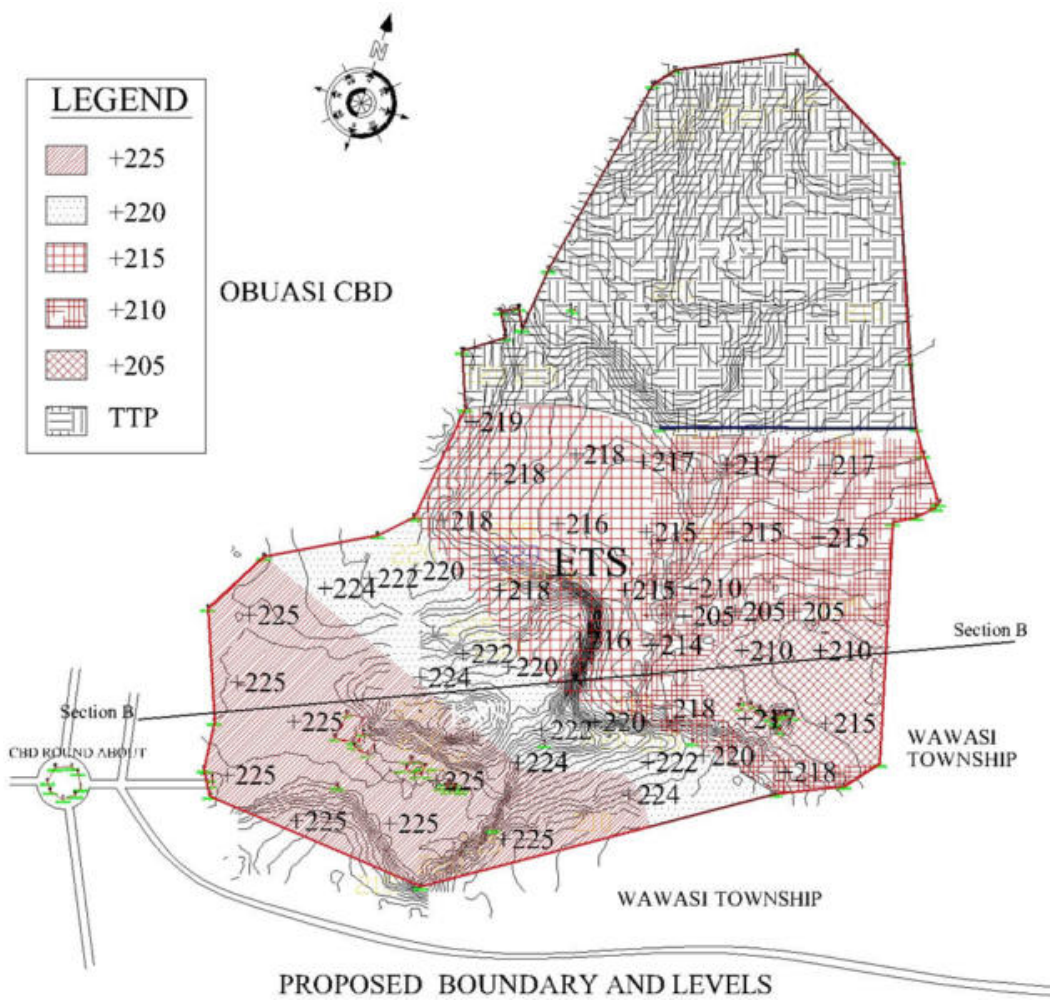

Figure 11. Reclaimed landform design. Source Authors, 2015 


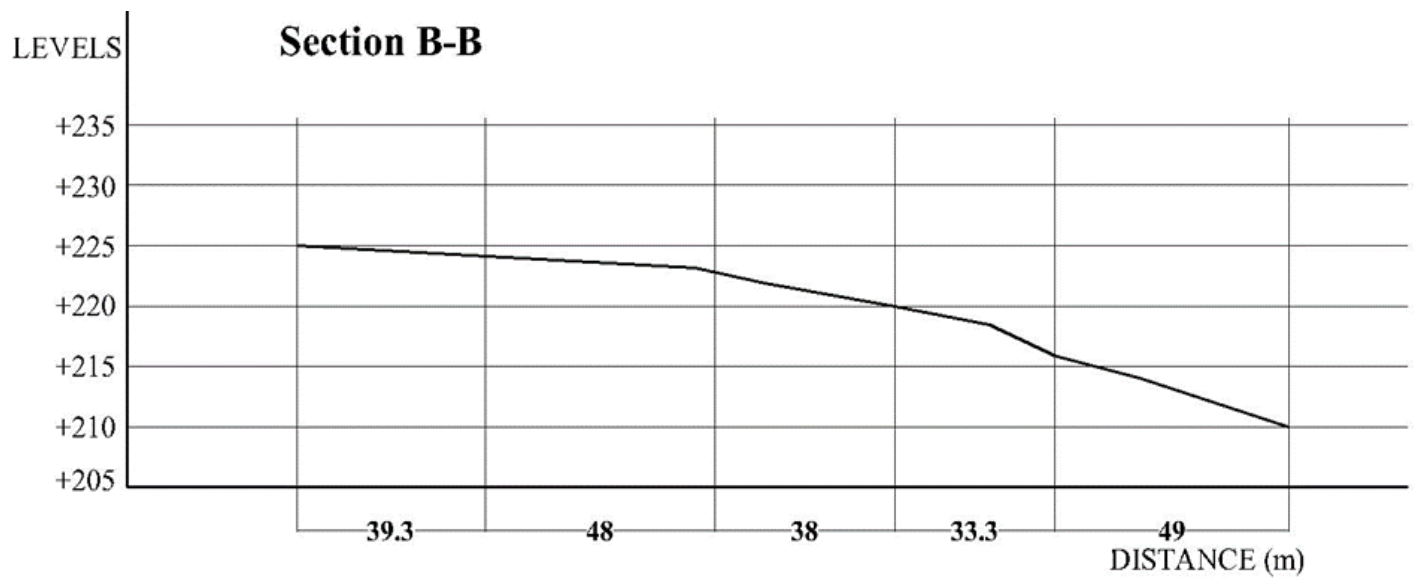

Figure 12. Cross section B-B through reclaimed landform design. Source Authors, 2015

The reclaimed landform design was then modelled (Figure 13) in three dimension (3D) surface and wireframe to show the reduced levels and filled lower levels to converge in a valley -drain toward the north (TTP) boarder.
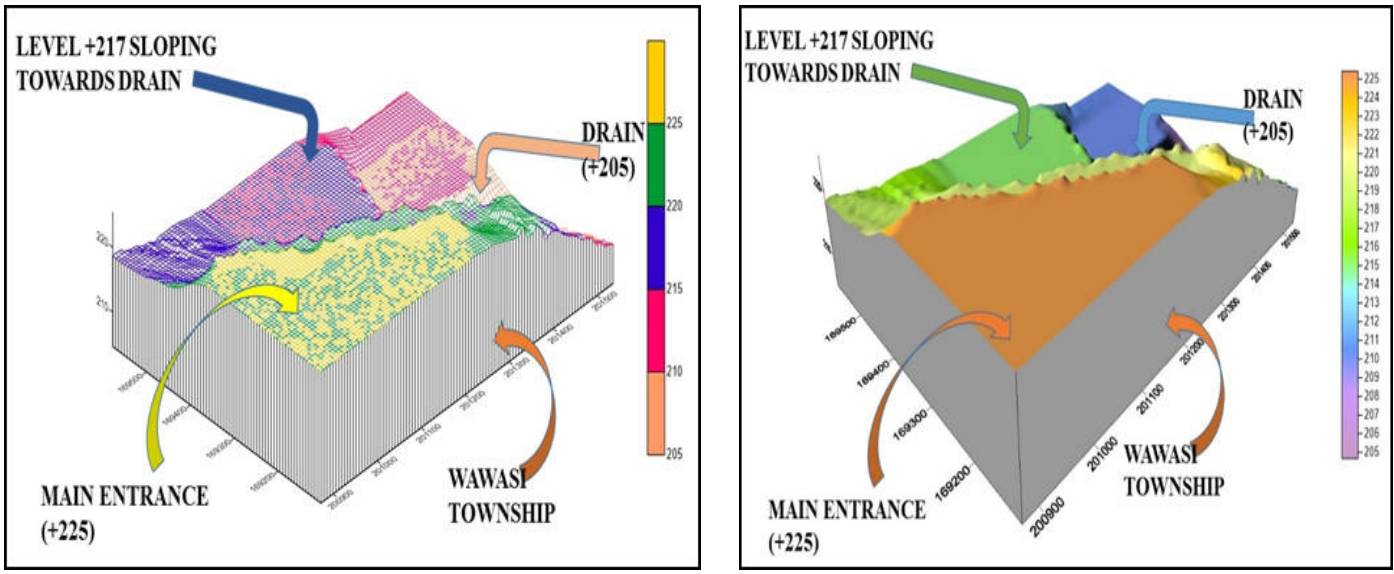

Figure 13. 3-D Surface and wireframe Model of the New Landform. Source: Authors, 2015

\subsection{Drainage Design}

The ETS area was divided into three catchment zones as shown in Figure 14 with the characteristics in Table 2.

Table 2: Catchment Areas

\begin{tabular}{|l|l|}
\hline Description & Catchment Area $\mathbf{( k m}^{\mathbf{2}} \mathbf{~}$ \\
\hline ETS & 0.218 \\
\hline TTP & 0.102 \\
\hline Embankment Slopes & 0.013 \\
\hline
\end{tabular}




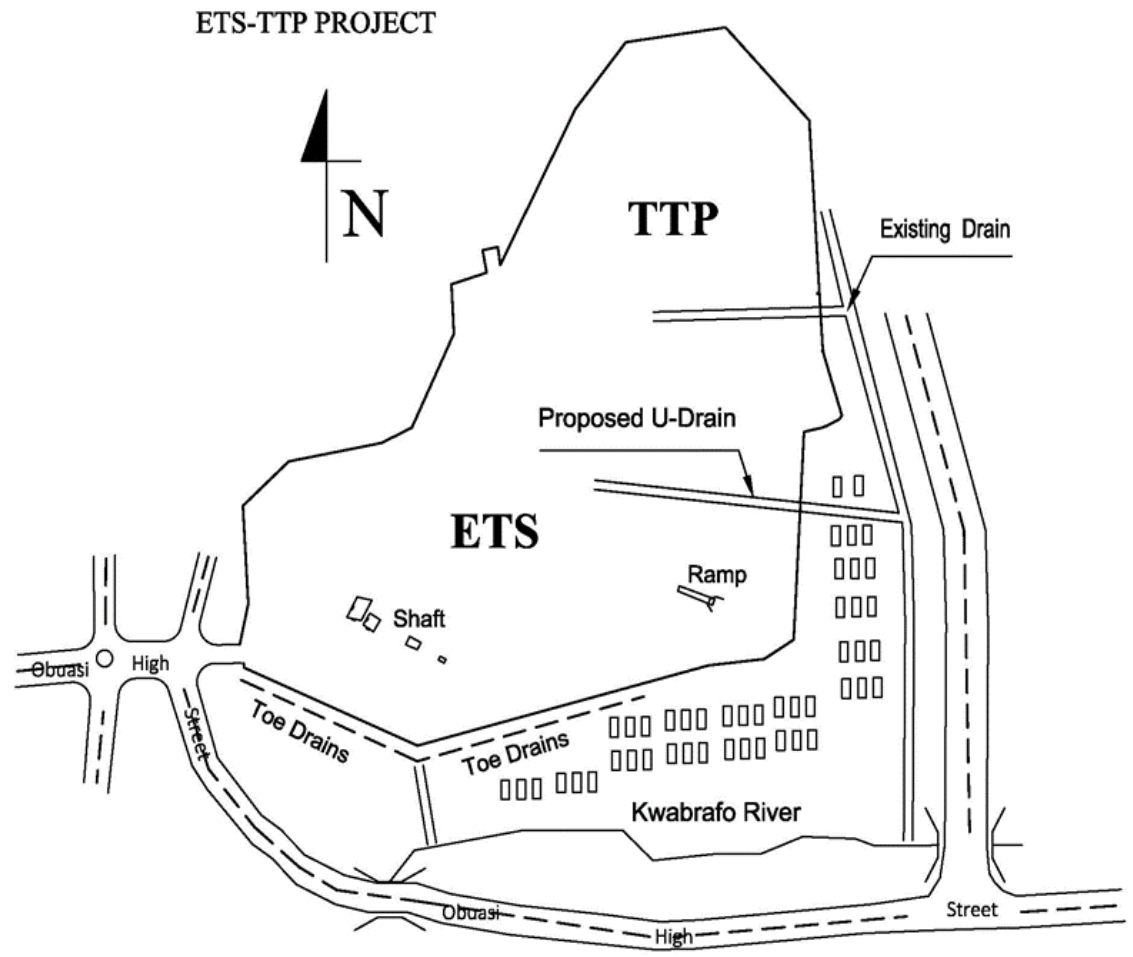

Figure 14. Catchment for Design

Using Kumasi as an adopted weather station, rainfall intensities for a 15 year return period (Road Design Guide) was computed. A runoff coefficient, C for forest zone of 0.3 (Road Design Guide) was used in calculating the expected runoff as presented in Table 3 .

Table 3: Expected Runoff

\begin{tabular}{|c|c|c|c|c|}
\hline Zone & Catchment Area (sq. km) & tc (hr) & $\begin{array}{c}\text { Rainfall Intensity, } \\
\text { I (mm/hr) }\end{array}$ & $\begin{array}{c}\text { Runoff Q (cub. } \\
\mathbf{m} / \mathbf{s e c})\end{array}$ \\
\hline ETS & 0.218 & 2.849 & 44.245 & 0.723 \\
\hline TTP & 0.196 & 2.336 & 53.888 & 0.980 \\
\hline Embankment Slope & 0.013 & 0.415 & 142.076 & 0.154 \\
\hline
\end{tabular}

A hydraulic analysis for the selected channel sections to determine the discharge capacities with $n=0.015$ is presented in Table 4.

Table 4: Results of Hydraulic Analysis

\begin{tabular}{|c|c|c|c|c|}
\hline Drain Type & Depth $(\mathbf{m})$ & Width $(\mathbf{m})$ & $\mathbf{S}(\mathbf{m} / \mathbf{m})$ & Qc $_{\mathbf{c}}\left(\mathbf{m}^{\mathbf{3}} / \mathbf{s e c}\right)$ \\
\hline U - Drain & 0.9 & 0.9 & 0.005 & 1.029 \\
\hline Rectangular & 0.4 & 0.6 & 0.004 & 0.233 \\
\hline
\end{tabular}

3.7 Stability of Slopes at the Project Site

For seismic considerations, even though Obuasi is within an area of low seismic activity in Ghana, a seismic coefficient of $0.15 \mathrm{~g}$ was applied in the analysis. The minimum factor of safeties obtained for the four embankment sections under static and seismic loading are summarized in Table 5. 
Table 5: Factors of Safety Obtained for Stability Analysis

\begin{tabular}{|c|c|c|c|c|}
\hline Proposed side slopes & \multicolumn{2}{|c|}{ FoS (Static) } & \multicolumn{2}{c|}{ FoS (Seismic) } \\
\cline { 2 - 5 } & Permissible & Obtained & Permissible & Obtained \\
\hline $\begin{array}{c}\text { Section 1 } \\
\text { (Slope with two embankments of slope 1:2) }\end{array}$ & 1.5 & 3.49 & 1.1 & 2.0 \\
\hline $\begin{array}{c}\text { Section 2 } \\
\text { (Slope with two embankments of slope 1:2) }\end{array}$ & 1.5 & 2.99 & 1.1 & 1.68 \\
\hline $\begin{array}{c}\text { Section 3 } \\
\text { (Slope with three embankments of slope } \\
1: 2 \text { ) }\end{array}$ & 1.5 & 3.13 & 1.1 & 1.74 \\
\hline $\begin{array}{c}\text { Section 4 } \\
\text { (Slope with two embankments of slope 1:2) }\end{array}$ & 1.5 & 3.49 & 1.1 & 2.0 \\
\hline
\end{tabular}

\section{Conclusions and Recommendations}

This landform design conforms to pre-existing catchment boundaries and drainage densities as recommended byToy and Chuse (2005). Arising from the fieldwork and design process, the following conclusions and recommendations have been formulated: The soils at the ETS have an upper stratum of sandy Gravels underlain by strata of silts or sands with average plasticity index of $14.46 \%$. Proctor compaction on the soils gave MDD and $\mathrm{OMC}$ averages of $1.683 \mathrm{~g} / \mathrm{cm} 3$ and $19.3 \%$ respectively. The mean allowable bearing capacity ranges between $781 \mathrm{KPa}$ and $1,413 \mathrm{KPa}$. The presence of waste rock fill overlying the natural ground resulted in very high values in the top soil. The elevations ranged from a minimum of $200 \mathrm{~m}$ to a maximum of $240 \mathrm{~m}$ with steep slopes at the south of the ETS. We recommend a designed landform which has a gentle slope transitions in the order of $2.5 \%$. Moreover, the excess soil should be used for filling to reduce cost of importing soil as the laboratory tests carried out on the soil samples showed that they can be used as fill material. A slope of 1:2 for the embankments gave satisfactory results to create erosionally stable design as affirmed by Hancock and Willgoose, (2017). For effective runoff management, the study recommends 900x900 $\mathrm{mm}$ U-drain to drain the ETS basin and a 400x600mm Rectangular drain at toe of the embankments. The reclaimed landform design serves as a basis for future restoration not only for the ETS area at Obuasi but other decommissioned mine areas in Ghana for sustainable development.

\section{Acknowledgement}

The authors appreciates particularly the management and staff of Anglogold Ashanti, Obuasi for their support and opportunity given to improve on the mined land for esustainable development of Obuasi and Ghana as a whole. We also express our sincere thanks to Sampson Kusi, and Joseph Osei Ababio for helping with data collection for throughout the project.

\section{References}

Akabzaa, T. \& Dramani, A. (2001). Impact of Mining Sector Investment in Ghana: A Draft report of a case study of the Tarkwa mining region prepared for SAPRI, 4-61.

Amonoo-Neizer, K. (1990). Code of Practice: Seismic Design of Concrete Structures, Ghana Building and Road Research Publication.

Amponsah, P.E. (2002). Seismic Activity in Relation to Fault Systems in Southern Ghana.

Aryee, B. N., Ntibery, B. K., \& Atorkui, E. (2003). Trends in the small-scale mining of precious minerals in Ghana: a perspective on its environmental impact. Journal of Cleaner Production. 11(2), 131-140.

Aryeetey, E., Osei, B. \& Twerefou, D.K. (2004). Globalization, Employment and Livelihoods in the Mining Sector of Ghana, 1980-2002, Institute of Statistical Social and Economics Research, Department of Economics, University of Ghana, Legon.

Asare-Awuku. (1991). Road Design Guide, Ghana Highway Authority. 
Babut, M., Sekyi, R., Rambaud, A., Potin-Gautier, M., Tellier, S. \& Bannerman, W. (2003). Improving the environmental management of small-scale gold mining in Ghana: a case study of Kumasi. Journal of Cleaner Production, 11(2), 215-221.

Bhattacharya, J. (2005). Reclamaition Methodologies for Displaced Landforms. Proceedings for Conference on Technological Advancements and Environmental Challenges in Mining and Allied Industries in the 21st Century, 5th - 6th February, NIT, Rourkela, 503-514.

Bonzongo, J. C., Donkor, A. K., \& Nartey, V. K., (2003).Environmental impacts of mercury related to artisanal gold mining in Ghana. In EDP sciences: 107. Journal de Physique IV, 217-220.

Bowles, J.E. (1997). Foundation Analysis and Design, 5th Edition, McGraw-Hill Books Co. Singapore. 1175.

Dankwa, J. B. (1974), Maximum Rainfall Intensity-Duration Frequencies in Ghana, Ghana Meteorological Services Departmental Note, 33.

Dickson, K.B. \& Benneh, G.A. (1988). New Geography of Ghana. Revised Edition, Longman Group, U.K. Ltd, 170.

Evans, K G, 2010. Development of trigger levels to assess catchment disturbance on stream suspended sediment loads in on stream suspended sediment loads in the Magela Creek, Northern Territory, Australia, Geographical Research, 48, 370-385.

Evans, D. M., Zipper, C. E., Burger, J. A., Strahm, B. D. \& Villamagna, A. M. (2013). Reforestation practice for enhancement of ecosystem services on a compacted surface mine: path toward ecosystem recovery. Ecological Engineering. 51, pp 16-23. DOI: 10.1016/j.ecoleng.2012.12.065.

Gavin, H. (2001). A Contextual Review of Small-Scale Mining Industry. Mining, Minerals and Sustainable development, 7 .

Ghana's Mining Portal (2013). Investors' Guide on Mineral Rights [online] Available: http://www.ghanamining.org/ghanaims/InvestorsGuide/. (February 18, 2017).

Ghana Statistical Service-GSS. (2012). Ghana Living Standards Survey (Round 6) from 18th October, 2012 to 17th October, 2013, GSS. [Online] Available: http://www.statsghana.gov.gh/docfiles/glss6/GLSS6_Main\%20Report.pdf (April 21, 2016).

Ghana Statistical Service-GSS. (2014). Revised Gross Domestic Product. [Online] Available: http://statsghana.gov.gh/docfiles/GDP/GDP2015/Revised_Annual_GDP2014_Jan2015. Pdf. (April 21, 2016.

Guzman, J. G., Lal, R., Byrd, S., Apfelbaum, S. I. \& Thompson, R. L. (2014). Carbon life cycle assessment for prairie as a crop in reclaimed mine land. Land Degradation \& Development 2014. DOI: 10.1002/ldr.2291.

Hancock, G.R., Loch, R.J. \& Willgoose, G.R., (2003). The design of post-mining landscapes using geomorphic principles. Earth Surface Processes and Landforms, 28(10), 1097-1110.

Hancock, G.R. \& Willgoose, G.R. (2017). Sustainable mine rehabilitation - 25 Years of the SIBERIA landform evolution and long-term erosion model, From Start to Finish: Life-of-mine Perspective, Australian Institute of Mining and Metallurgy, Carlton, 371-381.

Hilson, G. (2002). The environmental impact of small-scale gold mining in Ghana: identifying problems and possible solutions. Geographical Journal, 57-72.

Hilson, G. (2002b). Harvesting mineral riches: 1000 years of gold mining in Ghana. Resource Policy. 28, 13-26.

Hilson, G. \& Banchirigah, S.M. (2009). Are alternative livelihood projects alleviating poverty in mining communities? Experiences from Ghana. Journal of Development Studies. 45(2), 172-196.

Hu, Y. L., Niu, Z. X., Zeng, D. H. \& Wang, C. Y. (2015). Soil Amendment Improves Tree Growth and Soil Carbon and Nitrogen Pools in Mongolian Pine Plantations on Post - Mining Land in Northeast China.

Junner, N.R. (1941). The Accra Earthquake of 22nd June 1939, Gold Coast Geological Survey Bulletin 13, 3 41.

Kesse, G.O. (1985). The Mineral and Rock Resources of Ghana, A.A. Balkema Publishers.

Kindemba, V., Whitehouse, A. \& Peay, S. (2009). Using GIS to Prioritise and Identify Regional Ark Sites for Whiteclawed Crayfish: South West Aggregate and Mineral Extraction Sites. BugLife, Peterborough.

KPMG, (2014). GLOBAL MINING INSTITUTE. Ghana Country Mining Guide. 2014. [Online] Available: http://www.kpmg.com/GH/en/Documents/ghana-mining-guide\%202014.pdf. (April 21, 2016). 
Maconachie, R. and Binns, T. (2007). 'Farming miners' or 'mining farmers'? Diamond mining and rural development in post-conflict Sierra Leone. Journal of Rural Studies 23,367-380.

Madejon, E., de Mora, A.P., Felipe, E., Burgos, P., \& Cabrera, F. (2006). Soil amendments reduce trace element solubility in a contaminated soil and allow regrowth of natural vegetation. Environment Pollution. 139, 40-52.

National Environment Research Council (2015). "Restoration" Minerals UK, Centre for Sustainable Mineral Development, Open Research Archive.

Nicolau, J.M., (2003). Trends in relief design and construction in opencast mining reclamation. Land Degradation \& Development, 14(2), 215-226.

O'Kane M \& Wels C. (2003). Mine waste cover system design - linking predicted performance to groundwater and surface water impacts, 6th ICARD Conference Cairns, Queensland, 341-349.

Owusu-Ansah, F. (2012). Surface Mining and Perceived Risks: The Case of Three Farming Communities in the Brong-Ahafo Region, Ghana, 452, ISBN-13: 978-3659286858, LAP Lambert Academic Publishing AG \& Co KG, Germany.

Powter, C. B. (2002). Glossary of Reclamation and Remediation Terms Used in Alberta - 7th. Edition, Alberta Environment, Science and Standards Branch, Edmonton, Alberta. Pub. No. T/655;. Report No. SSB/LM/02-1, 88.

Quarry Products Association (2006). The Need for Inert Wastes to Restore Aggregate Mineral Workings, Position Statement.

Rinkesh (2009). Causes and effects of industrial pollution. Conserve energy future. [Online] Available: http://www.conserve-energy-future.com/causes-effects-of-industrial-pollution.php. (April 25, 2016).

SAPRIN (2002). Structural Adjustment Participatory Review International Network - The Policy Roots of Economic Crisis and Poverty: A Multi-Country Participatory Assessment of Structural Adjustment, SAPRIN, Washington, DC.

Skousen, J., \& Ziemkiewicz, P. (2012). Reclamation of Marcellus Shale Drilling Sites in West Virginia. 29th Annual Meeting - Sustainable Reclamation, ASMR Reclamation Matters. DEL Communications Inc., 26-30.

Sowers G.F. \& Hedges C.S., "Dynamic Cone for Shallow In-situ Penetration Testing”, ASTM STP 399, ASTM, 29.

Stephenson D. J. (1981). Stormwater Hydrology and Drainage, Elsevier Scientific Publishing Company, The Netherlands.

Toy, T. and Chuse, W., (2005). Topographic reconstruction: a geomorphic approach. Ecological Engineering, 24, 29-35.

United Kingdom Department of Communities and Local Development (2014). [Online]Available: https://www.gov.uk/government/publications/national-planning-policy-framework--2. (April 28, 2015). 